\title{
Farklı Beslenme Şekilleri ve İntestinal Mikrobiyota
}

\author{
Gül Eda KILINÇ i ${ }^{1}$, Aslı UÇAR 國 ${ }^{1}$
}

\begin{abstract}
ÖZ
Mikroorganizmalar bütün yaşayan çok hücreli organizmalarda bulunmaktadır. İntestinal mikrobiyota çok sayıda bakteriden oluşmakta ve kompozisyonu bireyden bireye göre farklılık göstermektedir. Diyet bileşenleri özellikle de makro besin ögeleri, intestinal mikrobiyotanın şekillenmesinde anahtar faktörlerden biri olup, yararlı bakterilerin azalması veya artmasında oldukça önem taşımaktadır. Ayrıca kısa süreli ve uzun süreli diyetler intestinal mikrobiyota profilini değiştirmekte ve çeşitli yolaklarla immün sistem mekanizmasını etkileyebilmektedir. Karbonhidratlar, intestinal mikrobiyotanın temel enerji kaynağı olup, sindirilebilir ve sindirilemeyen karbonhidratlar olarak yüksek karbonhidratlı diyetler intestinal mikrobiyota üzerinde farklı etkilere sahiptir. Yüksek yağlı diyetlerden özellikle Batı tarzı beslenmede düşük posa, yüksek yağ ve protein, rafine karbonhidratlar ile karakterize olup yararlı bakteriler olarak tanımlanan Bifidobacterium ve Eubacterium yoğunluğunda azalmaya sebep olmaktadır. İntestinal mikrobiyota diyetin protein içeriğinden etkilenmekte olup, intestinal mikrobiyota aynı zamanda glutamat ailesi, serin ailesi, aspartat ailesi, pirüvat ailesi ve aromatik aile gruplarından çeşitli aminoasitlerin sentezini gerçekleştirmektirmekte ve bu nedenle diyetin protein içeriği oldukça önem taşımaktadır. Bu derlemede, farklı beslenme şekillerinin intestinal mikrobiyota üzerine etkilerinin incelenmesi amaçlanmıştır.
\end{abstract}

Anahtar Kelimeler: İntestinal mikrobiyota; karbonhidrat; protein; yağ.

\section{ABSTRACT}

\section{Different Nutrition Types and Intestinal Microbiota}

Microorganisms are found in all living multicellular organisms as well as humans. İntestinal microbiota consists of a large number of bacteria and its composition varies for individual. Dietary components, especially macronutrients, are a key factor in formation of intestinal microbiota, and are important in reducing or increasing beneficial bacteria. In addition, short-term and long-term diets change the intestinal microbiota profile and may affect immune system mechanism by various pathways. Carbohydrates are main energy source of intestinal microbiota and high carbohydrate diets as digestible and non-digestible carbohydrates have different effects on intestinal microbiota. Especially in Western diet, in high-fat diets, which has low fiber, high fat and protein, characterized by refined carbohydrates, and causes a decrease in density which identified as beneficial bacteria, Bifidobacterium and Eubacterium. Intestinal microbiota is influenced by protein content of diet and intestinal microbiota is also involved in synthesis of various amino acids from glutamate family, serine family, aspartate family, pyruvate family and aromatic family groups, and therefore protein content of diet is very important. In this review, we aimed to investigate effects of different nutritional forms on intestinal microbiota.

Keywords: Intestinal microbiota; carbohydrate; protein; fat.

\section{GíRiş}

Mikroorganizmalar insan da dahil olmak üzere, bütün yaşayan çok hücreli organizmalarda bulunmaktadır. İnsan vücudu çok sayıda bakterinin, arkeanın, virüsün ve tek hücreli ökaryotların yaşama alanını oluşturmaktadır. Birbirleri ile uyum içinde yaşayan ve yaşadıkları konaklara yararlı olan mikroorganizmalara "mikrobiyota", "mikroflora" ya da normal flora denilmektedir (1). İnsan vücudunda bulunan hücrelerden 10 kat daha fazla olan mikroorganizma toplulukları,

1 Ankara Üniversitesi, Sağlık Bilimleri Fakültesi, Beslenme ve Diyetetik Bölümü, Ankara-Türkiye 
insan vücudunun çeşitli bölgelerinde kolonize halde bulunmaktadır. Çok uzun sürelerden bu yana, insanla simbiyotik bir yaşam sürdürmekte ve fizyolojik homeostazisi sağlamaktadır. İntestinal ortamda yaşayan mikroorganizmalar ise intestinal mikrobiyotay oluşturmaktadır. İntestinal mikrobiyota, mukozal bariyer zenginliğini arttıran gen ekpresyonunu düzenlemesi ve doğum sonrası bağırsak olgunlaşması gibi kendi fonksiyonlarından dolayı yeni bir insan organı olma düşüncesini de beraberinde getirmiştir (2). İntestinal mikrobiyota genetik faktörler yanında inflamasyon varlığı, yaş, antibiyotik kullanımı ve intestinal ortamın pH's1 gibi birçok faktörden etkilenmektedir. $\mathrm{Bu}$ ortamlarda meydana gelebilecek tüm değişiklikler intestinal mikroorganizmaların çoğalmasını ve baskınlık özelliklerini etkileyebilmektedir (3). Mikrobiyotayı etkileyen önemli etkenlerden biri de bireyin uyguladığ diyetin içeriği yani beslenme şeklidir. $\mathrm{Bu}$ çalışmada da farklı beslenme şekillerinin intestinal mikrobiyota üzerine etkilerinin incelenmesi amaçlanmıştır.

\section{İntestinal Mikrobiyota ve Beslenme Şekilleri \\ Yüksek Karbonhidratlı Diyetler}

Yüksek karbonhidratlı diyetlerin miktarına yönelik herhangi bir standart tanım olmamakla birlikte, farklı çalışmalarda farklı standartlar uygulanmaktadır. Ancak genel olarak diyetle alınan toplam enerjinin karbonhidratlardan gelen oranı \% 26'nın altında olduğunda 'Düşük karbonhidratlı diyet', \% 26 - \% 44 oranında olduğunda 'Orta dereceli karbonhidratlı diyet', $\% 45$ - \% 65 oranında olduğunda 'Normal karbonhidratlı diyet' ve $\% \quad 65$ üzerinde olduğunda 'Yüksek karbonhidratlı diyet' ifadesi kullanılmaktadır. Buna ek olarak toplam enerjinin karbonhidratlardan gelen oranı diyet makro besin ögelerinin diyetteki içeriğine göre değişim göstermektedir (4). Karbonhidratlar, intestinal mikrobiyotanın temel enerji kaynağı olup, sindirilebilir ve sindirilemeyen karbonhidratlar olarak iki grupta incelenmektedir. Sindirilebilir karbonhidratlar, ince bağırsakta enzimatik yolla glukoz, fruktoz, galaktoz gibi şekerlere parçalanmaktadır. Parçalanma sırasında oluşan bu bileşenler kan glukozunu arttırmakta ve bazıları insülin yanıtını uyarmaktadırlar. Normal bağırsak mikrobiyotasını anaerobik, aerobik ve fakültatif anaerobik bakteriler oluşturmakta ve toplamda yaklaşık 500-1000 arasında bakteri türü bulunmaktadır. En çok bulunan bakteri türleri ise Firmicutes, Bacteriodetes, Proteobacteria, Verrumicrobia, Actinobacteria, Fusobacteria ve Cyanobacteria türleridir. Bu bakteriler yoğunlukla bağırsak lümenine bulunmaktadır. Meyvelerden alınan glukoz, fruktoz ve sükroz ile Bifidobacteria yoğunluğu artış gösterirken, Bacteroides yoğunluğu azalmaktadır (5). Karbonhidratların intestinal mikrobiyotaya etkileri Tablo 1'de gösterilmiştir (6).

Tablo 1. Karbonhidratların intestinal mikrobiyotaya etkisi

\begin{tabular}{|c|c|c|c|c|}
\hline & Bifidobacteria & Bacteroides & Clostridia & Lactobacilli \\
\hline Glukoz & Artar & Azalır & & \\
\hline Fruktoz & Artar & Azalır & & \\
\hline Sükroz & Artar & Azalır & & \\
\hline Laktoz & Artar & Azalır & Azalır & Artar \\
\hline
\end{tabular}

Sindirilemeyen karbonhidratlar ise ince bağırsakta enzimatik yolla sindirime uğramamakta, ancak intestinal mikrobiyotada fermentasyona uğramakta ve intestinal mikrobiyota için asıl enerji ve karbon kaynağını oluşturmaktadır. Sindirilemeyen bu karbonhidratlar prebiyotik olarak adlandirılmakta ve intestinal mikrobiyotada yararlı mikroorganizmaların aktivitesini arttırmaktadır. Prebiyotikler; soya fasulyesi, inülin, rafine olmayan buğday, çiğ yulaf, fruktanlar, polidekstroz, fruktooligosakkaritler, galaktooligosakkaritler, ksilooligosakkaritler ve arabinooligosakkaritlerden oluşmaktadır. Bu bileşenleri içeren bir diyet ise bakteriyal yoğunlukta artış meydana getirmektedir (7). Spesifik bakterilere bakılmaksizın, sindirilemeyen karbonhidratların laktik asit bakterileri ve yararlı bakterileri arttırdığ 1 tam tahıllı besinlerin, yüksek posa içeriği nedeniyle intestinal mikrobiyota üzerinde olumlu etkiler yaptığı bildirilmiştir (8). Yapılan bir çalışmada, tahıllı kahvaltılık gevreklerin 3 hafta tüketiminden sonra bifidobakteri yoğunluğunun arttığı belirlenmiştir. Ayrıca Lactobacillus/Enterococcus oranı da artış göstermiştir (9). Bir diğer çalışmada da kahvaltılık gevreklerin tüketimi sonrasında Bifidobacterium yoğunluğunun ve Lactobacillus/Enterococcus oranının belirgin olarak arttığ1 tespit edilmiştir (10). Ancak Martinez ve arkadaşlarının (2013), çalışmasında tam tahıllı yulaflı ve tam tahıllı pirinç gevreklerinin tüketimiyle kısa zincirli yağ asitlerinde (KZYA) değişimin olmadı̆̆ belirlenmiştir. Bunun yanında Firmicutes oranının arttığı, Bacteroidetes filumlarının ise azaldığı saptanmıştır (11). Yapılan bir başka çalışmada 12 hafta sonrasında işlenmiş tam tahıllı ekmeklere kiyasla beyaz ekmeklerin Clostridium IV kümelerinde artışa neden olduğu bildirilmiştir (12). Bir başka çalışmada posalı besinlerin birkaç gün içerisinde intestinal mikrobiyotayı değiştirdiği saptanırken uzun dönem (3 hafta) sonrasinda filumlar arasında farklılık olmadığı tespit edilmiştir. Nişasta, ince bağırsaktan kolona uzanan bir yolda fermantasyona uğramakta olup, doğal granüller (RS2), retrograde nişasta (RS3), kimyasal olarak modifiye nişasta (RS4) gibi nişasta türleri dirençli nişasta olarak adlandırılmaktadır. Randomize bir çalışmada 14 hafif şişman çalışmaya dahil edilip 10 hafta süresince RS3 tüketmiş ve Ruminococcus bromii yoğunluğunda artış saptanmıştır (13). Ayrıca Oscillibacter ve Eubacterium rectale yoğunluğunda artış belirlenmiştir. Başka bir çalışmada 10 birey 3 hafta RS4 tüketmiş ve Actinobacteria ve Bacteroidetes yoğunluğunda artış Firmicutes yoğunluğunda azalma belirlenmiştir. Ayrıca Bifidobacterium adolescentis ve Parabacteroides distasonis yoğunluğunda da artış tespit edilmiştir (11). Bir başka çalışmada inülin, guar gam ve maltodekstrin ile yapılan bir karışımın konstipe kadınlarda Clostridium spp. türlerinde azalma sağladığı, ancak KZYA'lerinde değişiklik olmadığı belirlenmiştir (14). Bir başka çalışmada 3 hafta inülin kullanımı sonrasında Bifidobacterium yoğunluğunda ve Lactobacilli/Enterococci oranında artış belirlenmiştir. KZYA'nde ise değişiklik bildirilmemiştir (10). İnülin ve ksilooligosakkarit karışımının tüketildiği 60 sağlıklı birey ile yapılan bir çalışmada ise, Bifidobacterium ve bütirat yoğunluğunun arttığ1, lipopolisakkaritlerin ise azaldığ 1 belirtilmiştir (15). Prospektif çift kör yapılan bir çalışmada fruktooligosakkaritler içeren ve içermeyen 
diyetler uygulanmış ve 2 hafta sonrasında iki grupta da Faecalibacterium prausnitzii ve Roseburia intestinalis yoğunluğunun azaldığı saptanırken, KZYA yoğunluğu sadece posasız diyette azalmıştır (16). Galaktooligosakkaritler içeren ve içermeyen diyetlerin uygulandığı bir çalışmada ise 12 hafta sonrasında, GOS içeren diyette Bifidobacteria yoğunluğunda artış Bacteroides spp. ve Clostridium histolitycum yoğunluğunda azalma belirlenmiştir (17). Bir başka çalışmada 3 hafta polidekstroz alımı sonunda bütirat üreten bakteri olarak bilinen Ruminococcus intestinalis ve Clostridium I,II ve IV kümelerinde artış belirlenmiştir (10). Diğer bir çalışmada 50 erkek birey değerlendirilmiş olup, $25 \mathrm{~g}$ /gün dirençli maltodekstrin tüketiminin intestinal mikrobiyotayı değiştirmediği saptanmıştır. Buna ek olarak $50 \mathrm{~g}$ /gün tüketiminin ise intestinal mikrobiyota üzerinde hafif bir etki yarattığ belirlenmiştir (18). Prebiyotikler ve direçli nişastanın intestinal mikrobiyota üzerine etkileri Tablo 2'de özetlenmiştir (8, 9, 13, 19).

Yapılan bir çalışmada 12 hafta süresince kontrol grubu, içme sularına fruktoz eklenen grup ve yüksek yağlı beslenen ve içme sularına fruktoz eklenen grup olmak üzere fareler üç grupta incelenmiştir. Yüksek yağlı beslenen ve içme sularına fruktoz eklenen grupta mukus kalınlığında azalma ve ileumda defensin salınımında azalma saptanmıştır. Kontrol grubuna kıyasla Firmicutes/Bacteroidetes oranında ikinci grupta \% 88, üçüncü grupta \% 63 artış belirlenmiştir. Ancak yüksek yağlı beslenen ve içme sularına fruktoz eklenen grupta farklı bir şekilde Bifidobacterium yoğunluğunun daha fazla olduğu belirlenmiş ve bunun nedeninin yüksek yağ ve fruktozun Bifidobacterium türünün besin kaynağ1 olmasından kaynaklanabileceği belirtilmiştir (20).

Tablo 2. Prebiyotikler ve direçli nişastanın intestinal mikrobiyota üzerine etkileri

\begin{tabular}{|c|c|c|}
\hline & Posa/Prebiyotik & Dirençli Nişasta \\
\hline Bakteriyel & Artar & Artar \\
\hline Gen Zenginliği & Artar & Artar \\
\hline Lactobacilli & Artar & Artar \\
\hline Bifidobacteria & Artar & \\
\hline Clostridia & Azalır & \\
\hline Enterococcus & Artar/Azalır & \\
\hline Roseburia & & Artar \\
\hline Euminiococcus & & Artar \\
\hline & & \\
\hline
\end{tabular}

Bir başka çalışmada 4 ay süresince yüksek yağ ve sükroz olan grup, yüksek yağ ve fruktoz olan grup, kontrol grubu şeklinde gruplar oluşturulmuş ve kontrol grubuna kıyasla yüksek yağ ve sükroz grubunda $\% 51$, yüksek yağ ve fruktoz grubunda \% 19'luk ağırlık artışı tespit edilmiştir. Ayrıca yüksek yağ ve sükroz grubunda beden kütle indeksi, glukoz intoleransı, lipopolisakkaritler, insülin seviyesi, renal oksidatif stres, malondialdehit artış belirlenirken, antioksidan enzimler ve yağsız vücut kütlesinde azalma saptanmıştır. Her iki grupta da kontrol grubuna kiyasla Coprococcus eutactus yoğunluğunun arttığı belirlenmiştir (21). Bir diğer çalışmada Swiss tür farelerle içme sularına \% 20 lik fruktoz solüsyonu eklemesi yapılmış ve 6 hafta izlem sonrasında kontrol grubuna kıyasla fruktoz ilavesi yapılan grupta leptin seviyeleri ve Bacteroidetes seviyelerinde artış, Firmicutes türlerinde azalma tespit edilmiştir (22).

\section{Yüksek Proteinli Diyetler}

Yüksek proteinli diyete ilişkin çeşitli görüşler bulunmakta olup, besin sanayisinde besinin toplam enerjisinden gelen oran \% 20'den daha fazla olduğu durumda 'proteinden zengin' ifadesi kullanılmakta, ağırlık kaybına yönelik diyetlerde ise genel olarak diyetten gelen toplam enerjinin proteinden gelen oran $1 \%$ 30 ve üzerinde olduğunda 'Yüksek Proteinli Diyet' ifadesi kullanılmaktadır (23). İntestinal mikrobiyota diyetin protein içeriğinden etkilenmekte olup, intestinal mikrobiyota aynı zamanda glutamat ailesi, serin ailesi, aspartat ailesi, pirüvat ailesi ve aromatik aile gruplarından çeşitli aminoasitlerin sentezini gerçekleştirmektedir. Diyet proteinlerinin intestinal mikrobiyotaya ilk etkisi 1977 yılında belirlenmiştir. Yüksek biftek tüketimi (176 g protein), kontrol grubu (86 g protein) ve et içermeyen diyetin (90 g protein) karşılaştırıldığı bir çalışmada yüksek biftek tüketiminin olduğu grupta Bacteroides ve Clostridia yoğunluğunun arttı̆̆ 1 Bifidobacterium adolescentis yoğunluğunun ise azaldığ1 belirlenmiştir (24). Ancak bezelye proteini gibi bitkisel proteinlerin ve whey proteininin Bifidobacterium ve Lactobacillus yoğunluğunu arttırdığı ve patojen özellikte olan Bacteroides fragilis ve Clostridium perfringens yoğunluğunu azalttığı saptanmıştır (25). Ek olarak özellikle bezelye proteini KZYA yoğunluğunda artış sağlamakta ve mukozal bariyerde antiinflamatuar etki sağlamaktadır. Bunun aksine hayvansal proteinler, Bacteroides, Alistipes ve Bilophila gibi anaerob bakterilerin artmasına neden olmaktadır (19). İtalyan çocuklarla Afrikalı çocukların karşılaştırıldığı bir çalışmada, hayvansal proteinleri fazla tüketen İtalyan çocukların mikrobiyotalarının Bacteroides ve Alistipes türlerinden zengin olduğu saptanmıştır (26). Yüksek hayvansal protein tüketimiyle inflamatuar bağırsak hastalığının tetiklenebileceği belirtilmektedir. Ayrıca önerilenin üzerinde kırmızı et tüketimi ile birçok intestinal mikroorganizma türü artış göstermekte ve kardiyovasküler risk için proaterojenik olan trimetilamine--N-oksit (TMAO) seviyesinde artış meydana gelmektedir (27). Ancak bunun yanında mikrobiyal protein sentezini destekleyecek nitelikte bir diyet (bitkisel proteinli) sonucunda intestinal mikroorganizma oluşan azotu kullanarak üreye dönüştürmekte ve renal sağlığa katkıda bulunmaktadır 
(28). Bir başka çalışmada 20 wistar rata 6 hafta süresince $\% \quad 20$ ve $\% 45$ protein içeren proteinli diyetler uygulanmış, yüksek proteinli diyet grubunda Escherichia coli yoğunluğunda artış, Akkermansia muciniphila, Bifidobacterium, Prevotella, Ruminococcus bromii ve Roseburia/Eubacterium oranında, asetat, propiyonat ve bütirat yoğunluğunda, kolonik lümende IgG seviyelerinde azalma tespit edilmiştir (29). Yüksek proteinli bir diyet sonrasinda rat modellerinde, 15 gün süre sonunda intestinal lümen mitokondrilerinde proton sızıntısı nedeniyle kolonosit yüzeyinde deformasyonlar, kolonositlerde DNA hasarı ve intestinal lümende toksisite belirlenmiştir (30). Bir başka çalışmada Wistar erkek ratlarda 2 hafta süresince $\% 14$ proteinli ve $\% 53$ proteinli izokalorik diyetler uygulanmış ve yüksek protein tüketen grupta ince bağırsak, çekum ve kolonda IgA seviyelerinin azaldığı, feçeste ise artış gösterdiği saptanmıştır (31). Protein türlerinin intestinal mikrobiyotaya etkisi Tablo 3'te gösterilmiştir (26).

Tablo 3. Protein türlerinin intestinal mikrobiyotaya etkisi

\begin{tabular}{|c|c|c|c|}
\hline & $\begin{array}{c}\text { Hayvansal } \\
\text { Protein }\end{array}$ & $\begin{array}{c}\text { Whey } \\
\text { Proteini }\end{array}$ & $\begin{array}{c}\text { Bezelye } \\
\text { Proteini }\end{array}$ \\
\hline Mikrobiyal Çeşitlilik & Artar & Artar & Artar \\
\hline Bifidobacteria & Azalır/Artar & Artar & Artar \\
\hline Lactobacilli & & Artar & Artar \\
\hline Bacteroides & Azalır/Artar & Azalır & \\
\hline Alistipes & Artar & & \\
\hline Bilophilia & Artar & & \\
\hline Clostridia & Artar & Azalır & \\
\hline & & & \\
\hline & & & \\
\hline & & & \\
\hline & & & \\
\hline & & & \\
\hline & & & \\
\hline & & & \\
\hline & & & \\
\hline & & & \\
\hline & & & \\
\hline
\end{tabular}

\section{Yüksek Yağlı Diyetler}

Yüksek yağlı diyetlerin tüketimi kalp damar hastalıkları için risk faktörü olup, diyette tekli ve çoklu doymamış yağların kullanımının bu riski azalttığı belirtilmektedir. Tipik Batı diyeti, doymuş yağlardan zengin tekli ve çoklu doymamış yağlardan fakir olup, başta obezite olmak üzere birçok sağlık problemine neden olmaktadır. Ayrıca Batı tarzı beslenme düşük posa, yüksek yağ ve protein, rafine karbonhidratlar ile karakterize olup yararlı bakteriler olarak tanımlanan Bifidobacterium ve Eubacterium yoğunluğunda azalmaya sebep olmaktadır (32). Yapılan bir çalışmada İtalyan toplumuna kıyasla avc1 ve toplayıc1 Hadza-Tanzanya toplumunda benzer sonuç elde edilmiştir. Ayrıca Afrika toplumunda Succinivibrio ve Treponema yoğunluğu belirlenmiş olup bu bakteriler sindirilemeyen posanın sindirimine gerçekleştirmekte ve Afrika toplumunda bu bakterilere adaptasyonun olduğu belirlenmiştir. Bunun yanında Hadza toplumunda Bifidobacteria saptanmamıştır. Çünkü Hadza toplumu avc1-toplayıc1 bir toplum olup, Bifidobacteria türleri de tarımsal beslenme ile oluşabilmektedir (33).

Fava ve arkadaşları (2013), diyet yağ içeriklerinin intestinal mikrobiyotaya etkilerini araştırmış ve düşük yağlı diyet tüketimi ile Bifidobacterium yoğunluğunun arttığı ve bununla birlikte açlık glukozu ve total kolesterolün düştüğünü belirtmişlerdir. Diğer bir yandan tekli doymamış yağ asidi ile beslenmenin bakteriyel gen zenginliğine etki etmediği belirlenirken, total bakteri yükünü ve LDL kolesterolü azalttığı saptanmıştır. Yüksek yağlı diyet tüketimi ile Faecalibacterium prausnitzii oranlarının ve daha çok asetat ve propiyonat üreten Clostridiales, Bacteroides, ve Enterobacteriales gibi türlerin arttığı, Lactobacillus intestinalis türünün ise azaldığı saptanmıştır (34). Ayrıca balık yağının da intestinal mikrobiyota üzerine olumlu etkileri bulunmaktadır. Yapılan bir çalışmada domuz yağı ile beslenen farelerde Bacteroides ve Bilophila yoğunluğunda artış saptanırken, balık yağı ile beslenen farelerde Actinobacteria (Bifidobacterium ve Adlercreutzia), laktik asit bakterileri (Lactobacillus ve Streptococcus), ve Verrucomicrobia (Akkermansia muciniphila) yoğunluğunda artış belirlenmiştir. Domuz yağı ile beslenen farelerde balık yağı ile beslenen farelere kıyasla, sistemik TLR aktivasyonu ve beyaz adipoz doku inflamasyonu artarken, insülin duyarlılığında bozulmaların olduğu saptanmıştır (35). Yüksek yağlı diyet ve diyet yağlarının intestinal mikrobiyotaya etkisi Tablo 4'te özetlenmiştir (19, 32, 34, 36, 37).

Tablo 4. Yüksek yağlı diyet ve diyet yağlarının intestinal mikrobiyotaya etkisi

\begin{tabular}{|c|c|c|c|c|}
\hline & $\begin{array}{c}\text { Yüksek } \\
\text { Yağlı }\end{array}$ & $\begin{array}{c}\text { Düşük } \\
\text { Yağlı }\end{array}$ & $\begin{array}{c}\text { Doymuş } \\
\text { Yăg }\end{array}$ & $\begin{array}{c}\text { Doymamış } \\
\text { Yağ }\end{array}$ \\
\hline Laktik Asit & Azalır & & & \\
\hline Bifidobacteria & & Artar & & Artar \\
\hline Clostridiales & Artar & & & \\
\hline Bacteroides & Artar & & Artar & \\
\hline Bilophila & & & & \\
\hline & & & Artar & \\
\hline $\begin{array}{c}\text { Faecalibacterium } \\
\text { mukermansia }\end{array}$ & & & & \\
\hline
\end{tabular}




\section{Vegan Diyetlerin İntestinal Mikrobiyota Üzerine} Etkileri

Vejetaryen beslenme; bitkisel besinlerin tüketilip, hayvansal besinlerin sınırlı miktarda veya hiç tüketilmediği beslenme tarzı iken, vegan beslenmede hiçbir şekilde hayvansal besin tüketilmemektedir (38). Vejetaryen-vegan beslenme tarzının intestinal mikrobiyotayı etkilediği belirtilmekte ve bu ilişkiyi inceleyen çalışma sayıları kısıtlı sayıda bulunmaktadır. Genellikle vejetaryenlerde Bacteroides/Prevotella oranının, Bacteroides thetaiotaomicron, Clostridium IV kümeleri, Clostridium clostridioforme ve Faecalibacterium prausnitzii yoğunluğunda artışı olduğu belirtilmiştir (39). Yapılan bir çalışmada vegan ve vejetaryen diyetlerle kontrol grubu karşılaştırıldığında, Bifidobacterium ve Bacteroides yoğunluğunda belirgin azalma saptanmıştır (40). Bir diğer çalışmada ise vejetaryen ve omnivorlar arasında intestinal mikrobiyota açısında anlamlı farklılık belirlenmemiştir. Ancak vejetaryenlerde Bacteroides yoğunluğu artarken Clostridium IV kümelerinin azaldığı tespit edilmiştir (3). Sonuç olarak vejetaryen-vegan beslenenenlerle ilgili çalışmalarda büyük sınırlamalar, metodolojideki sorunlar ve gönüllü sayılarının yetersizliğinde dolayı bu tarz beslenme ve intestinal mikrobiyota ile ilgili net sonuçlar söyleyebilmek mümkün değildir.

\section{Glutensiz Diyet ve Akdeniz Diyetinin İntestinal Mikrobiyota Üzerine Etkileri}

Glutensiz ve Akdeniz diyeti de intestinal mikrobiyotay 1 etkileyen diyet türleri arasında yer almaktadır. Glutensiz diyetin etkilerini inceleyen bir çalışmada 10 sağlıklı birey 30 gün boyunca glutensiz diyet ile beslenmiş ve yararlı bakteriler olarak nitelendirilen Bifidobacterium ve Lactobacillus türlerinde azalma, patojen bakteri olarak nitelendirilen E. coli ve Enterobacteriaceae yoğunluğunda artış tespit edilmiştir (2). Bir başka çalışmada ise kısa süreli glutensiz diyet uygulaması sonucunda Ruminococcus bromii ve Roseburia faecis türlerinde azalma, Victivallaceae ve Clostridiaceae türlerinde artı̧̧ saptanmıştır (1). Akdeniz diyeti tekli ve çoklu doymamış yağ asitlerinden zengin yağ asidi profili ve yüksek düzeyde polifenol ve antioksidan gibi sağlıklı beslenme örüntülerini içermekte olup, intestinal mikrobiyota üzerine olumlu etkileri mevcuttur. Akdeniz diyetine yüksek uyum ile KZYA'lerinde Prevotella ve diğer Firmicutes yoğunluğunda artış bildirilmiştir. Bunun yanında Akdeniz diyetine düşük uyum ile ürede kardiyovasküler hastalıklar için risk faktörü olan trimetilamin oksit seviyesinde artış belirlenmiştir (27). Çoğu çalışmada Akdeniz diyetinin aynı zamanda obezite, lipid profili ve inflamasyon üzerine de olumlu etkileri bulunmaktadır. Ayrica Akdeniz diyeti ile Lactobacillus, Bifidobacterium ve Prevotella yoğunluğunun arttığı Clostridium yoğunluğunun azaldığı tespit edilmiştir (36). Bazı diyet türlerinin intestinal mikrobiyotaya etkisi Tablo 5 'te özetlenmiştir $(1,2,27,32)$.

\section{SONUÇ VE ÖNERILER}

Görüldüğü gibi, intestinal mikrobiyota birçok faktörden etkilenmekte olup en önemli etmenlerden biri de bireyin diyetinin içeriğidir. Hatalı ve sağlıksız diyet uygulamaları ile intestinal mikrobiyota olumsuz yönde etkilenmekte ve birçok sağlık sorununun oluşumuna zemin hazırlanabilmektedir. Optimal bir intestinal mikrobiyotaya sahip olabilmek için sağlıklı beslenme alışkanlıkları ve yaşam tarzına sahip olunması gerekmektedir. Ancak intestinal mikrobiyota ve beslenme şekilleri ilişkisini inceleyen deneysel araştırmaların yetersizliğinden dolayı hangi bakteri türünün hangi besin tüketimiyle azalıp artabileceğini ve dolayısıyla hangi hastalıklara zemin hazırlayabileceğini net olarak söyleyebilmek şu an için mümkün değildir.

Tablo 5. Bazı diyet türlerinin intestinal mikrobiyotaya etkisi

\begin{tabular}{|c|c|c|c|}
\hline & $\begin{array}{c}\text { Batı } \\
\text { Tarzı } \\
\\
\text { (Yüksek } \\
\text { Yağ ve } \\
\text { Yüksek } \\
\text { Protein) }\end{array}$ & $\begin{array}{c}\text { Akdeniz } \\
\text { (Yüksek Posa, } \\
\text { Antioksidanlar) }\end{array}$ & $\begin{array}{c}\text { Glutensiz } \\
\text { (Glutensiz) }\end{array}$ \\
\hline Bifidobacteria & Azalır & Artar & Azalır \\
\hline Lactobacilli & Azalır & Artar & Azalır \\
\hline Prevotella & & Artar & Azalır \\
\hline Eubacteria & Azalır & Artar & Azalır \\
\hline Roseburia & & Artar & Azalır \\
\hline Bacteroides & Artar & Artar & Azalır \\
\hline Enterobacteria & Artar & & Artar \\
\hline
\end{tabular}

Yazarların Katkıları: Fikir/Kavram: G.E.K.; Tasarım: G.E.K.; Literatür Taraması: G.E.K., A.U.; Makale Yazımı: G.E.K.; Eleştirel İnceleme: G.E.K., A.U.

\section{KAYNAKLAR}

1. Bonder MJ, Tigchelaar EF, Cai X, Trynka G, Cenit MC, Hrdlickova B, et al. The influence of a shortterm gluten-free diet on the human gut microbiome. Genome medicine. 2016; 8(1): 45.

2. Sanz Y. Effects of a gluten-free diet on gut microbiota and immune function in healthy adult humans. Gut Microbes. 2010; 1(3): 135-7.

3. Liszt K, Zwielehner J, Handschur M, Hippe B, Thaler R, Haslberger AG. Characterization of bacteria, clostridia and Bacteroides in faeces of vegetarians using qPCR and PCR-DGGE fingerprinting. Ann Nutr Metab. 2009; 54(4): 253-7. 
4. Jung C-H, Choi KM. Impact of high-carbohydrate diet on metabolic parameters in patients with type 2 diabetes. Nutrients. 2017; 9(4): 322.

5. Eid N, Enani S, Walton G, Corona G, Costabile A, Gibson G, et al. The impact of date palm fruits and their component polyphenols, on gut microbial ecology, bacterial metabolites and colon cancer cell proliferation. J. Nutr. Sci. 2014; 3.

6. Parvin S, Easmin D, Sheikh A, Biswas M, Sharma SCD, Jahan MGS, et al. Nutritional analysis of date fruits (Phoenix dactylifera L.) in perspective of Bangladesh. American Journal of Life Sciences. 2015; 3(4): 274-8.

7. Pandey KR, Naik SR, Vakil BV. Probiotics, prebiotics and synbiotics-a review. J Food Sci Technol. 2015; 52(12): 7577-87.

8. Halmos EP, Christophersen CT, Bird AR, Shepherd SJ, Gibson PR, Muir JG. Diets that differ in their FODMAP content alter the colonic luminal microenvironment. Gut. 2015; 64(1): 93-100.

9. Carvalho-Wells AL, Helmolz K, Nodet C, Molzer C, Leonard C, McKevith B, et al. Determination of the in vivo prebiotic potential of a maize-based whole grain breakfast cereal: a human feeding study. Br J Nutr. 2010; 104(9): 1353-6.

10. Costabile A, Fava F, Röytiö H, Forssten SD, Olli K, Klievink J, et al. Impact of polydextrose on the faecal microbiota: a double-blind, crossover, placebocontrolled feeding study in healthy human subjects. Br J Nutr. 2012; 108(3): 471-81.

11. Martinez I, Lattimer JM, Hubach KL, Case JA, Yang $\mathrm{J}$, Weber CG, et al. Gut microbiome composition is linked to whole grain-induced immunological improvements. ISME J. 2013; 7(2): 269.

12. Lappi J, Salojarvi J, Kolehmainen M, Mykkänen H, Poutanen K, de Vos WM, et al. Intake of whole-grain and fiber-rich rye bread versus refined wheat bread does not differentiate intestinal microbiota composition in Finnish adults with metabolic syndrome. J Nutr. 2013; 143(5): 648-55.

13. Walker AW, Ince J, Duncan SH, Webster LM, Holtrop G, Ze X, et al. Dominant and diet-responsive groups of bacteria within the human colonic microbiota. ISME J. 2011; 5(2): 220.

14. Waitzberg DL, Pereira C, Logullo L, Jacintho TM, Almeida D, SILVA M, et al. Microbiota benefits after inulin and partially hydrolized guar gum supplementation-a randomized clinical trial in constipated women. Nutr Hosp. 2012.

15. Lecerf J-M, Depeint F, Clerc E, Dugenet Y, Niamba $\mathrm{CN}$, Rhazi L, et al. Xylo-oligosaccharide (XOS) in combination with inulin modulates both the intestinal environment and immune status in healthy subjects, while XOS alone only shows prebiotic properties. Br. J. Nutr. 2012; 108(10): 1847-58.

16. Benus RF, van der Werf TS, Welling GW, Judd PA, Taylor MA, Harmsen HJ, et al. Association between Faecalibacterium prausnitzii and dietary fibre in colonic fermentation in healthy human subjects. Br. J. Nutr. 2010; 104(5): 693-700.

17. Vulevic J, Juric A, Tzortzis G, Gibson GR. A mixture of trans-galactooligosaccharides reduces markers of metabolic syndrome and modulates the fecal microbiota and immune function of overweight adults. J Nutr. 2013; 143(3): 324-31.

18. Baer DJ, Stote KS, Henderson T, Paul DR, Okuma K, Tagami H, et al. The metabolizable energy of dietary resistant maltodextrin is variable and alters fecal microbiota composition in adult men. J Nutr. 2014; 144(7): 1023-9.

19. Cotillard A, Kennedy SP, Kong LC, Prifti E, Pons N, Le Chatelier E, et al. Dietary intervention impact on gut microbial gene richness. Nature. 2013; 500(7464): 585.

20. Volynets V, Louis S, Pretz D, Lang L, Ostaff MJ, Wehkamp J, et al. Intestinal barrier function and the gut microbiome are differentially affected in mice fed a western-style diet or drinking water supplemented with fructose. J Nutr. 2017; 147(5): 770-80.

21. Rosas-Villegas A, Sánchez-Tapia M, Avila-Nava A, Ramírez V, Tovar A, Torres N. Differential effect of sucrose and fructose in combination with a high fat diet on intestinal microbiota and kidney oxidative stress. Nutrients. 2017; 9(4): 393.

22. Zubiría M, Gambaro S, Rey M, Carasi P, Serradell M, Giovambattista A. Deleterious metabolic effects of high fructose intake: the preventive effect of Lactobacillus kefiri administration. Nutrients. 2017; 9(5): 470.

23. Johnstone AM. Safety and efficacy of high-protein diets for weight loss. Proc Nutr Soc. 2012; 71(2): 33949.

24. Hentges DJ, Maier BR, Burton GC, Flynn MA, Tsutakawa RK. Effect of a high-beef diet on the fecal bacterial flora of humans. Cancer Res. 1977; 37(2): 568-71.

25. Dominika S, Arjan N, Karyn RP, Henryk K. The study on the impact of glycated pea proteins on human intestinal bacteria. Int. J. Food Microbiol. 2011; 145(1): 267-72.

26. De Filippo C, Cavalieri D, Di Paola M, Ramazzotti M, Poullet JB, Massart S, et al. Impact of diet in shaping gut microbiota revealed by a comparative study in children from Europe and rural Africa. Proc Natl Acad Sci. 2010; 107(33): 14691-6.

27. De Filippis F, Pellegrini N, Vannini L, Jeffery IB, La Storia A, Laghi L, et al. High-level adherence to a Mediterranean diet beneficially impacts the gut microbiota and associated metabolome. Gut. 2016; 65(11): 1812-21.

28. Levine ME, Suarez JA, Brandhorst S, Balasubramanian P, Cheng C-W, Madia F, et al. Low protein intake is associated with a major reduction in IGF-1, cancer, and overall mortality in the 65 and younger but not older population. Cell Metab. 2014; 19(3): 407-17.

29. Mu C, Yang Y, Luo Z, Zhu W. Temporal microbiota changes of high-protein diet intake in a rat model. Anaerobe. 2017; 47: 218-25.

30. Singh RK, Chang H-W, Yan D, Lee KM, Ucmak D, Wong $\mathrm{K}$, et al. Influence of diet on the gut microbiome and implications for human health. J. Transl. Med. 2017; 15(1): 73.

31. Lan A, Andriamihaja M, Blouin J-M, Liu X, Descatoire V, de Maredsous CD, et al. High-protein diet differently modifies intestinal goblet cell 
characteristics and mucosal cytokine expression in ileum and colon. J Nutr Biochem. 2015; 26(1): 91-8.

32. Wu GD, Chen J, Hoffmann C, Bittinger K, Chen Y$\mathrm{Y}$, Keilbaugh SA, et al. Linking long-term dietary patterns with gut microbial enterotypes. Science. 2011; 334(6052): 105-8.

33. Schnorr SL, Candela M, Rampelli S, Centanni M, Consolandi C, Basaglia G, et al. Gut microbiome of the Hadza hunter-gatherers. Nat Commun. 2014; 5: 3654.

34. Lecomte V, Kaakoush NO, Maloney CA, Raipuria M, Huinao KD, Mitchell HM, et al. Changes in gut microbiota in rats fed a high fat diet correlate with obesity-associated metabolic parameters. PloS one. 2015; 10(5): e0126931.

35. Caesar R, Tremaroli V, Kovatcheva-Datchary P, Cani PD, Backhed F. Crosstalk between gut microbiota and dietary lipids aggravates WAT inflammation through TLR signaling. Cell Metab. 2015; 22(4): 658-68.

36. Fava F, Gitau R, Griffin B, Gibson G, Tuohy K, Lovegrove $\mathrm{J}$. The type and quantity of dietary fat and carbohydrate alter faecal microbiome and short-chain fatty acid excretion in a metabolic syndrome 'atrisk'population. Int J Obes. 2013; 37(2): 216.

37. Urwin HJ, Miles EA, Noakes PS, Kremmyda L-S, Vlachava M, Diaper ND, et al. Effect of salmon consumption during pregnancy on maternal and infant faecal microbiota, secretory $\operatorname{IgA}$ and calprotectin. Br J Nutr. 2014; 111(5): 773-84.

38. Melina V, Craig W, Levin S. Position of the Academy of Nutrition and Dietetics: vegetarian diets. J Acad Nutr Diet. 2016; 116(12): 1970-80.

39. Matijasic BB, Obermajer T, Lipoglavsek L, Grabnar I, Avguštin G, Rogelj I. Association of dietary type with fecal microbiota in vegetarians and omnivores in Slovenia. Eur J Nutr. 2014; 53(4): 1051-64.

40. Wu GD, Compher C, Chen EZ, Smith SA, Shah RD, Bittinger $\mathrm{K}$, et al. Comparative metabolomics in vegans and omnivores reveal constraints on dietdependent gut microbiota metabolite production. Gut. 2016; 65(1): 63-72. 